\title{
Macroinvertebrate responses to algal and bacterial manipulations in streams
}

\author{
Randall L. Fuller*, Brian P. Kennedy ${ }^{1} \&$ Carl Nielsen \\ Biology Department, Colgate University, Hamilton, NY 13346-1398, USA \\ ${ }^{1}$ Present address: 2534 C.C. Little Building, Department of Geological Sciences, University of Michigan, \\ Ann Arbor, MI 48109 USA \\ (*Author for correspondence: Tel.: +1-315-228-7393, Fax: +1-315-228-7997,E-mail: rfuller@mail.Colgate.edu)
}

Received 29 May 2002; in revised form 22 January 2004; accepted 1 March 2004

Key words: macroinvertebrate feeding, trophic relations, food quality, stream periphyton, microbial communities, Chironomidae

\begin{abstract}
Our study was designed to assess the relative importance of algae and bacteria as sources of energy for stream macroinvertebrates. In one experiment, we manipulated algae by artificially shading six sections in each of two streams, one stream with an open canopy (clear-cut drainage basin) and the other with a closed canopy (forested drainage basin); both streams were in Hubbard Brook Experimental Forest, New Hampshire, USA. Chlorophyll $a$ concentrations were reduced from 0.2 to $0.05 \mu \mathrm{g} / \mathrm{cm}^{2}$ in artificially shaded sections of both streams. However, macroinvertebrates showed no response to these algal manipulations in either the clear-cut or forested stream. Nutrient concentrations ( $\mathrm{N}$ and $\mathrm{P}$ ) were low and limiting to primary production in both the clear-cut and forested streams. Additionally, both streams had relatively low macroinvertebrate densities suggesting bottom-up controls were important in macroinvertebrate abundance. However, the forested stream did have higher macroinvertebrate densities presumably because of higher inputs of coarse particulate organic matter from the riparian vegetation. In a second experiment, in Augusta Creek, Michigan, we manipulated both algae and bacteria. To reduce algae, we artificially shaded experimental stream channels so that chlorophyll $a$ was reduced from natural levels of 3.0-5.6 to 0.4$0.7 \mu \mathrm{g} / \mathrm{cm}^{2}$. Half of the shaded channels had dissolved organic carbon (DOC - sucrose) dripped into them to raise DOC levels by $2-3 \mathrm{mg} / \mathrm{l}$ and thus stimulate bacterial abundance. Open channels, with higher algal abundance, had higher densities of Ephemerella, but only in November when nymphs were larger. Channels with increased DOC had higher bacterial abundances, higher densities of Chironomidae and lower densities of Heptageniidae. Several other macroinvertebrate taxa that were at relatively low abundance in our samples showed no significant response to these manipulations. Our results suggest that early instar Ephemerella may not rely as heavily on algae as later instars. Also, certain taxa were able to use the heterotrophic microbial community, especially chironomids which increased in numbers when bacterial density increased; thus, the bacterial carbon source may be more important to some stream macroinvertebrates than previous studies have suggested.
\end{abstract}

\section{Introduction}

Numerous studies have addressed the relative importance of autochthonous versus allochthonous carbon inputs to stream macroinvertebrates in the past two decades. Traditional approaches have combined gut content analyses and invertebrate secondary production to estimate the trophic basis of production of stream macroinvertebrate communities (Benke \& Wallace, 1980, 1997; Benke 
\& Jacobi, 1994; Hall et al., 2001). More recently, methodological advances using stable isotopes have permitted the tracing of terrestrial and algal carbon sources through stream food webs (Hamilton \& Lewis, 1992; Rosenfeld \& Roff, 1992; Junger \& Planas, 1994; Huryn et al., 2001; Zah et al., 2001, McCutchan \& Lewis 2002). These studies have drawn different conclusions about the relative importance of allochthonous versus autochthonous sources, perhaps because of the wide variety of stream settings in which these studies have been performed, ranging from the Arctic tundra to equatorial rainforests.

Previous studies have shown shifts in macroinvertebrate community composition between forested and open-canopy streams (Vannote et al., 1980; Behmer \& Hawkins, 1986; see review by Wallace \& Webster, 1996), and many studies have reported greater macroinvertebrate abundance or production in open-versus closed-canopy streams. These results suggest algae may support greater macroinvertebrate production at least in part because of its greater assimilation efficiency (Benke \& Wallace, 1980; Fuller \& Mackay, 1981). In the past decade, however, emphasis has been placed on terrestrial derived inputs to streams (Wallace et al., 1995, 1999). Hall et al. (2001) showed that allochthonous rather than autochthonous carbon supported the majority of secondary production in two very different streams, one of which was an open canopy, fifth order stream with low terrestrial inputs and high incident radiation. Hall et al. (2001) concluded that algae were probably nutrient-limited and thus autochthonous carbon was less important than one might have expected in a fifth order stream. However, McCutchan \& Lewis (2002) have shown that algae support almost half the macroinvertebrate secondary production in a forested stream.

Few studies have addressed the role of bacteria in stream food webs (but see Hall et al., 2000). In laboratory growth studies of stream insects, algal diets did not always promote the most growth when compared to those of leaf detritus or bacteria (Hauer \& Benke, 1987; Fuller et al., 1988; Fuller \& Fry, 1991). In fact, bacteria have been shown to produce higher growth rates than algae in certain insect families (including Simuliidae, Heptageniidae, Leptophlebiidae) (Hauer \& Benke, 1987; Fuller et al., 1988; Fuller \& Fry, 1991). Field studies, too, have shown that some macroinvertebrates rely heavily on bacteria as a source of energy (Mulla \& Lacey, 1976; Edwards \& Meyer, 1990). In a series of studies (Hall, 1995, Hall \& Meyer, 1998; Hall et al., 2000, 2001), stable isotopes of carbon were used to label bacteria in headwater streams and demonstrated the importance of bacterial carbon to several stream taxa, including the mayfly Stenonema, chironomids, and copepods.

There is strong evidence, therefore, from both laboratory growth and stable isotope manipulations for the importance of bacteria in macroinvertebrate growth and production, however only one study has manipulated bacterial densities in streams and measured the response by the macroinvertebrate community (Warren et al., 1964). In that study, Warren et al. increased bacterial abundance by adding labile carbon sources (sucrose) to a stream in Oregon, which resulted in an increase in Chironomidae abundance, but not in other macroinvertebrates. However, because this study did not manipulate algae and bacteria separately, the macroinvertebrate response could not be attributed solely to bacteria or their indirect effects on algae. In order to establish the relative roles of bacterial and algal abundance on aquatic insect populations, our study builds upon these previous results by simultaneously manipulating algal and bacterial abundance as food sources for a macroinvertebrate community.

This study combines two separate manipulations of energy sources to small (second-third order) streams. The overall objective of our studies was to quantify the response of an entire macroinvertebrate community to manipulations in algal and bacterial resources in streams. In the first study, we attempted to assess the importance of autochthonous material by manipulating incident light to lower primary productivity in 12 forested and clear-cut stream pools in low nutrient streams at Hubbard Brook Experimental Forest (HBEF), New Hampshire, USA. Our second study builds upon the results of the first experiment in two ways; first, the second set of experiments were conducted in an agriculturally impacted stream, Augusta Creek, in Michigan, USA where nutrients were not limiting to primary producers. Consequently, a bottom-up manipulation of macroinvertebrates mediated through light could show 
stronger effects. Secondly, by incorporating an additional manipulation of bacterial densities in the study design, we could quantify how species in a macroinvertebrate community respond to simultaneous manipulations in their basal resources.

\section{Study sites}

\section{Hubbard Brook tributaries}

The first experiment was conducted at HBEF in the White Mountains of central New Hampshire which has been described in many previous publications (e.g., Bormann \& Likens, 1979). This experiment, hereafter referred to as HBEF, was conducted in two streams, one with a closed canopy and the other with an open canopy, in adjacent catchments during summer 1989. The closed-canopy stream in catchment 6 (Bear Brook) flowed through a deciduous forest. The opencanopy stream (in catchment 5) flowed through a catchment that was clear-cut in 1983; so, the riparian vegetation had been recovering for 6 years at the time of our experiment. The forested and clear-cut streams are second order, with high gradients and dramatic changes in depth and discharge during and after rainfall. Our study was conducted in pools $\left(6-8 \mathrm{~m}^{2}\right.$ in area) with depths ranging from 20 to $60 \mathrm{~cm}$. Nutrient concentrations were low (mean values for June-December 1988 and 1989 for the clear-cut and forested stream, respectively, $\mathrm{NO}_{3-} ; \mathrm{N}=25.4$ and $67.2 \mu \mathrm{g} / 1 ; \mathrm{PO}_{4-}^{-}$ $; \mathrm{P}=5.7$ and $5.7 \mu \mathrm{g} / 1 ; \mathrm{DOC}=2.14$ and $1.7 \mathrm{mg} / \mathrm{l})$ in both streams during this study.

\section{Augusta Creek}

The second experiment was performed in Augusta Creek in south-central Michigan. The study site is a third order stream and has an open canopy with riparian vegetation consisting primarily of various herbs, grasses, shrubs (primarily Salix) and a few scattered tamarack trees (Larix laricina). The stream is approximately $5 \mathrm{~m}$ wide with depths ranging from 10 to $50 \mathrm{~cm}$. Substrates consist of cobbles and pebbles embedded in sand and gravel. This stream is in an agricultural area where nutrient inputs are substantially higher (mean values for fall $1990, \quad \mathrm{NO}_{3}-\mathrm{N}=1.024 \mathrm{mg} / \mathrm{l}$; $\mathrm{DOC}=4.73 \mathrm{mg} / \mathrm{l}$ ) than in HBEF.

\section{Methods}

\section{Hubbard Brook experiments}

During the third week of May 1989, 120 wire mesh cages $(15 \mathrm{~cm} \times 10 \mathrm{~cm} \times 5 \mathrm{~cm}$; mesh $1.25 \mathrm{~cm} \times$ $1.25 \mathrm{~cm}$ ) were filled with gravel and placed in 12 pools in each stream ( 5 cages/pool). Four weeks later (26 June), six pools in each stream were artificially shaded using weed barrier cloth suspended over the stream at heights $<1 \mathrm{~m}$. Light levels measured with a LiCor spherical light sensor under the shade cloth were $1 \%$ of light intensity outside the shade cloth. Ambient light was $49 \pm 71 \mu \mathrm{mol} \mathrm{m}^{-2} \mathrm{~s}^{-1}$ (mean $\left.\pm 1 \quad \mathrm{SD}, n=20\right)$ for the forested stream and $433 \pm 418 \mu \mathrm{mol} \mathrm{m}{ }^{-2}$ $\mathrm{s}^{-1}(n=14)$ for the clear-cut stream. Between each of the artificially shaded sites on each stream were pools with natural canopies. Therefore, there were six artificially shaded sites and six natural canopy sites in each stream (the clear-cut stream having higher light intensities).

Macroinvertebrate density was estimated in June just prior to the shade cloth being suspended over pools using the introduced cages. Collection of cages continued every 3 weeks through September. Estimates were made by removing a pair of cages from each pool and combining cage contents for each pair; one replicate would then consist of all the macroinvertebrates in the $2 \mathrm{ca}$ ges/pool combined. Thus, for each sampling period, we collected six replicates of each treatment (natural canopy and artificially shaded) in each stream (forested and clear-cut). Macroinvertebrates were removed from the cages, preserved (80\% ethanol), identified and counted. Cages with substrates were returned to the stream and marked with colored wire (different colors to designate different introduction dates) to ensure a minimum of 6 weeks for re-colonization before being collected again.

Algae were quantified by incubating unglazed tiles for 1 month in both artificially shaded and natural canopy sections in both streams. Chlorophyll $a$ was extracted from periphyton on tiles in basic methanol overnight and concentrations were 
determined on a fluorometer after centrifuging to remove debris. Chlorophyll standards were obtained from SIGMA. Acidification $(50 \mu \mathrm{l}$ of $\mathrm{HCl}$ per $5 \mathrm{ml}$ sample) was used to correct for phaeophytin pigments.

Bacterial abundance was estimated after sonicating tiles for 2 min to remove attached cells. Cell suspensions were stained with acridine orange, collected on a $0.2 \mu \mathrm{m}$ Nuclepore filter and counted with an Olympus BH-2 epifluorescent microscope at $1250 \times$ magnification (Hobbie et al., 1977).

Beginning with the 25 August samples, we quantified coarse particulate organic matter (CPOM) in the cages by removing all gravel and pebbles (2 cages/sample) and rinsing and decanting all organic particulates from the sample. This material was collected using a $1 \mathrm{~mm}$ mesh sieve, dried for $48 \mathrm{~h}$ at $60{ }^{\circ} \mathrm{C}$ and then weighed on a Sartorius balance $( \pm 0.1 \mathrm{mg})$.

Densities of specific taxa were compared among treatments (natural canopy versus artificially shaded pools) and streams (forested versus clear-cut) using a two-way ANOVA for each sample date. CPOM abundance between streams was compared using a $t$-test.

\section{Augusta Creek experiments}

These experiments were conducted in 24 experimental channels in which we manipulated algae (by artificial shading) and bacteria (through DOC amendments). Channels were made of plywood $(2.4 \mathrm{~m} \times 15 \mathrm{~cm} \times 40 \mathrm{~cm}) \quad$ with 3 channels $/ \mathrm{set}$ (eight sets). All channels were placed in the stream on 24 August and light and DOC manipulations began on 14 September. For each set, two channels were shaded with weed barrier cloth $(99 \%$ light reduction) and the other was open. Also, we added sucrose to one of the shaded channels in each set to increase DOC and thus increase heterotrophic microbial abundance.

Sucrose was added to the channels using 1251 plastic garbage cans containing a needle-type spigot at the bottom. Twice each week (3- and 4-day intervals) depth and current velocity measurements (Pygmy flow meter) were measured in each channel and discharge was calculated to determine the amount of sucrose needed to elevate DOC concentrations by $2-3 \mathrm{mg} / 1$. The sugar was then dissolved in concentrated form in 3.81 jugs and added to the garbage cans along with filtered stream water $(90 \mu \mathrm{m}$ mesh sieve) to bring the volume of water up to 961 . Drip rates were set at $1 \mathrm{l} / \mathrm{h}$ however, because head pressure decreased as the volume in the can decreased, drip rates were monitored and adjusted daily. Spates sometimes caused variations in discharge, which meant channels had to be raised and lowered regularly (sometimes twice daily) in order to maintain a relatively constant flow through channels. We determined the average increase in DOC in the sucrose amended channels for each period (3 or 4 days) using the volume of sucrose dispensed from each can and the average discharge rate (using the initial and final discharge volumes for each period) according to the following formula:

$$
\begin{aligned}
& \text { Increase in DOC }(\mathrm{mg} / 1) \\
& \quad=S /\left\{\left[\left(Q_{\mathrm{I}}+Q_{\mathrm{F}}\right) / 2\right] \times T\right\}
\end{aligned}
$$

where $S$ is the amount of sucrose dispensed from the barrel over a single period $(\mathrm{mg} / \mathrm{l}$ in barrel $\times$ volume delivered), $Q_{\mathrm{I}}$ is the discharge measured at the beginning of a period, $Q_{\mathrm{F}}$ is the discharge measured at the end of a period, and $T$ is the time of period in seconds.

Macroinvertebrates were sampled using wire mesh cages (filled with gravel) similar to those used in the Hubbard Brook study, but these cages were larger $(20 \mathrm{~cm} \times 15 \mathrm{~cm} \times 5 \mathrm{~cm})$. The 136 cages $(16$ extra to allow for loss) were placed in a riffle section of Augusta Creek on 3 June 1990 and left for more than 2 months to allow natural colonization by algae and macroinvertebrates. On 24 August, all channels were placed in the stream and five cages were placed directly on the plywood bottom in the upstream half of each channel. To obtain a comparison of initial conditions among channels, we removed 1 cage/channel on 13 September, before manipulating light and sucrose. Samples were then taken at approximately 3-weeks intervals (although the 17 November set of samples was delayed 1 week because of a spate). Macroinvertebrates from each cage were rinsed from the gravel/pebble substrates and preserved in separate bottles with $80 \%$ ethanol. We randomly selected six samples for processing from each treatment/sample date. Subsamples ( 0.5 or 0.25 of original) were taken and macroinvertebrates were identified and counted. 
Unglazed clay tiles $(5 \mathrm{~cm} \times 5 \mathrm{~cm} \times 0.6 \mathrm{~cm})$ were placed in the stream in June and left until August to allow colonization by periphyton. On 24 August, colonized tiles were placed directly on the plywood floor in the downstream half of the channels and a piece of hardware cloth (mesh size $1.25 \mathrm{~cm} \times 1.25 \mathrm{~cm}$ ) rested $2 \mathrm{~cm}$ above the floor of the channel and about $0.5 \mathrm{~cm}$ above the tiles to prevent them from being washed out of their respective channels during spates. These tiles were used to estimate chlorophyll $a$ concentration and biofilm ash free dry mass (AFDM). On each sample date, two tiles were removed from each channel; one tile was used for chlorophyll $a$ analysis and the other for AFDM. Tiles for chlorophyll $a$ analysis were scraped onto Gelman glass fiber $(\mathrm{GF} / \mathrm{F})$ filters, ground in a tissue grinder and stored in $90 \%$ acetone overnight. Chlorophyll $a$ concentration (corrected for phaeophytin) was determined spectrophotometrically. AFDM was determined by scraping all material from the upper surface of a tile onto a pre-ashed Gelman glassfiber filter ( $1.2 \mu \mathrm{m}$ pore size), which was then dried for $24 \mathrm{~h}$ at $60{ }^{\circ} \mathrm{C}$, weighed, ashed in a muffle furnace at $500{ }^{\circ} \mathrm{C}$ for $2 \mathrm{~h}$, and weighed again.

Bacterial densities also were estimated using unglazed clay tiles $(2.5 \mathrm{~cm} \times 2.5 \mathrm{~cm} \times 0.6 \mathrm{~cm})$ that were placed in Augusta Creek from June to August and then placed directly on the plywood floor in the downstream half of each channel. One tile/channel was removed on each sample date, the periphyton was scraped into a Whirlpak bag and $20 \mathrm{ml}$ of $5 \%$ buffered formalin was added. The scrapings were then sonicated in a waterbath sonicator for 2$4 \mathrm{~min}$. Aliquots were removed from the bag, stained with acridine orange, and filtered onto prestained Nucleopore filters $(0.2 \mu \mathrm{m})$; bacteria were counted in 10 randomly chosen fields under a Zeiss epifluorescence microscope at $1250 \times$ magnification.

\section{Data analyses}

Data for macroinvertebrate densities, chlorophyll $a$ concentration, AFDM, and bacterial densities were first $\log$ transformed $\left(y=\log _{10}[x+1]\right.$, where $x$ is the density or biomass value) to produce a normal distribution, and these transformed values were compared separately using a two-way ANOVA for each sample date for Hubbard Brook data (main effects being light and stream). For the
Augusta Creek data, we did a one-way ANOVA for each sample date. To test for differences among treatments we used a Tukey-Kramer multiple comparison test.

\section{Results}

\section{Forested versus clear-cut streams}

Chlorophyll $a$ concentration was significantly lower (ANOVA, $p<0.05$ ) in the artificially shaded pools than in the natural canopy pools for both streams (Fig. 1). However, chlorophyll levels were extremely low $\left(<0.2 \mu \mathrm{g} / \mathrm{cm}^{2}\right)$ in both streams/treatments. Bacterial abundance was not significantly different $(p>0.05)$ between clear-cut and forested streams (Fig. 1) nor was there a difference in bacterial abundance between light treatments within streams. CPOM in cages was significantly greater $(p<0.01)$ in the forested stream than in the clear-cut stream on 22 August and 29 September. CPOM did not differ significantly between artificially shaded and natural canopied sites within a stream (Table 1).

Macroinvertebrate density was lower than what we expected, especially for the clear-cut stream. The most abundant macroinvertebrates were the chironomids, Heterotrisocladius hirtapex Saether and Thiennemanimyia and the stoneflies, Leuctra tenella and Capniidae. Algivorous caddisflies (Neophylax and Psilotreta) were present but at densities that were too low to show a significant response to our manipulations. Of the abundant macroinvertebrates, all but Capniidae had significantly greater densities $(p<0.01)$ in the forested stream than in the clear-cut stream. Capniidae density was similar between streams (Fig. 2). There was no response by any macroinvertebrate species to the light manipulations in either stream (Figs. 23 ). Overall, there was a much larger site effect than light treatment effect with differences in abundance of individual species between the streams explaining more than $40 \%$ of the total variability in the data sets (with the exception of Capniidae).

Augusta Creek - open, shaded and shaded + sucrose channels

We successfully increased sucrose concentrations in shaded + sucrose channels by $2-3 \mathrm{mg} / 1$ 

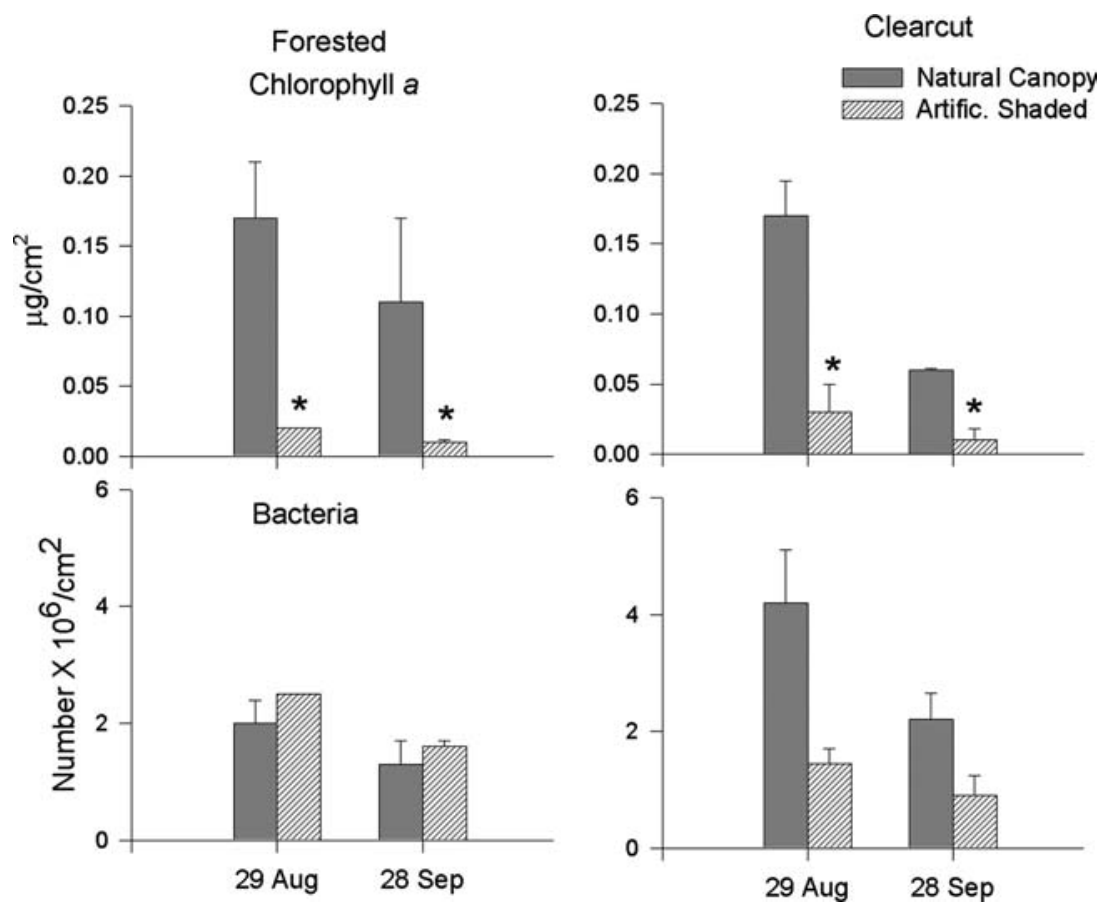

Figure 1. Mean (+1 SE, $n=6)$ chlorophyll $a$ concentration and bacterial density in two streams at HBEF on two different sample dates during summer 1989. (*above the bars indicate significant differences at $p<0.05$ ).

throughout most of the experimental period with the exception of two brief periods ( $<1$ day) when spates prevented sucrose additions. DOC additions coupled with our artificial shading resulted in a successful manipulation of both algal and bacterial abundance. Chlorophyll $a$ concentration was similar among treatments on 13 September (before light and sucrose manipulations) but was significantly reduced by 3 October in the 16 shaded channels (Fig. 4). Chlorophyll $a$ continued to decline in shaded channels until 30 October and thereafter remained at about $0.7 \mu \mathrm{g} / \mathrm{cm}^{2}$; however, in the open channels chlorophyll $a$ concentration was $3-4 \mu \mathrm{g} / \mathrm{cm}^{2}$ (Fig. 4). Bacterial abundance was lowest on 13 September and increased in all treatments through 30 October (Fig. 4). However, bacterial abundance increased more rapidly and remained significantly higher $(p<0.001)$ in the open and shaded + sucrose channels than in the shaded only treatment (Fig. 4). Following a severe spate on 9 November, bacterial abundance on 18 November was reduced in all treatments; but, open and shaded + sucrose treatments still had significantly $(p<0.001)$ more bacteria than the shaded treatment.

AFDM was not significantly different $(p>0.20)$ among treatments on 13 September prior to any light or sucrose manipulations

Table 1. Mean ( $\pm 1 \mathrm{SE})$ dry weight of CPOM in basket cages from two streams at HBEF during summer 1989

\begin{tabular}{|c|c|c|}
\hline & Forested stream $\mathrm{g} / 0.1 \mathrm{~m}^{2}$ & Clear-cut stream $\mathrm{g} / 0.1 \mathrm{~m}^{2}$ \\
\hline \multicolumn{3}{|l|}{26 August } \\
\hline Natural canopy & $8.68 \pm 1.63^{\mathrm{a}}$ & $4.37 \pm 1.01^{\mathrm{b}}$ \\
\hline Artificially shaded & $11.62 \pm 2.36^{\mathrm{a}}$ & - \\
\hline \multicolumn{3}{|l|}{29 September } \\
\hline Natural canopy & $13.98 \pm 3.40^{\mathrm{a}}$ & $2.29 \pm 0.56^{\mathrm{b}}$ \\
\hline Artificially shaded & $11.21 \pm 2.05^{\mathrm{a}}$ & $4.13 \pm 0.69^{\mathrm{b}}$ \\
\hline
\end{tabular}

Different superscript letters designate significant differences with $p<0.05$. 

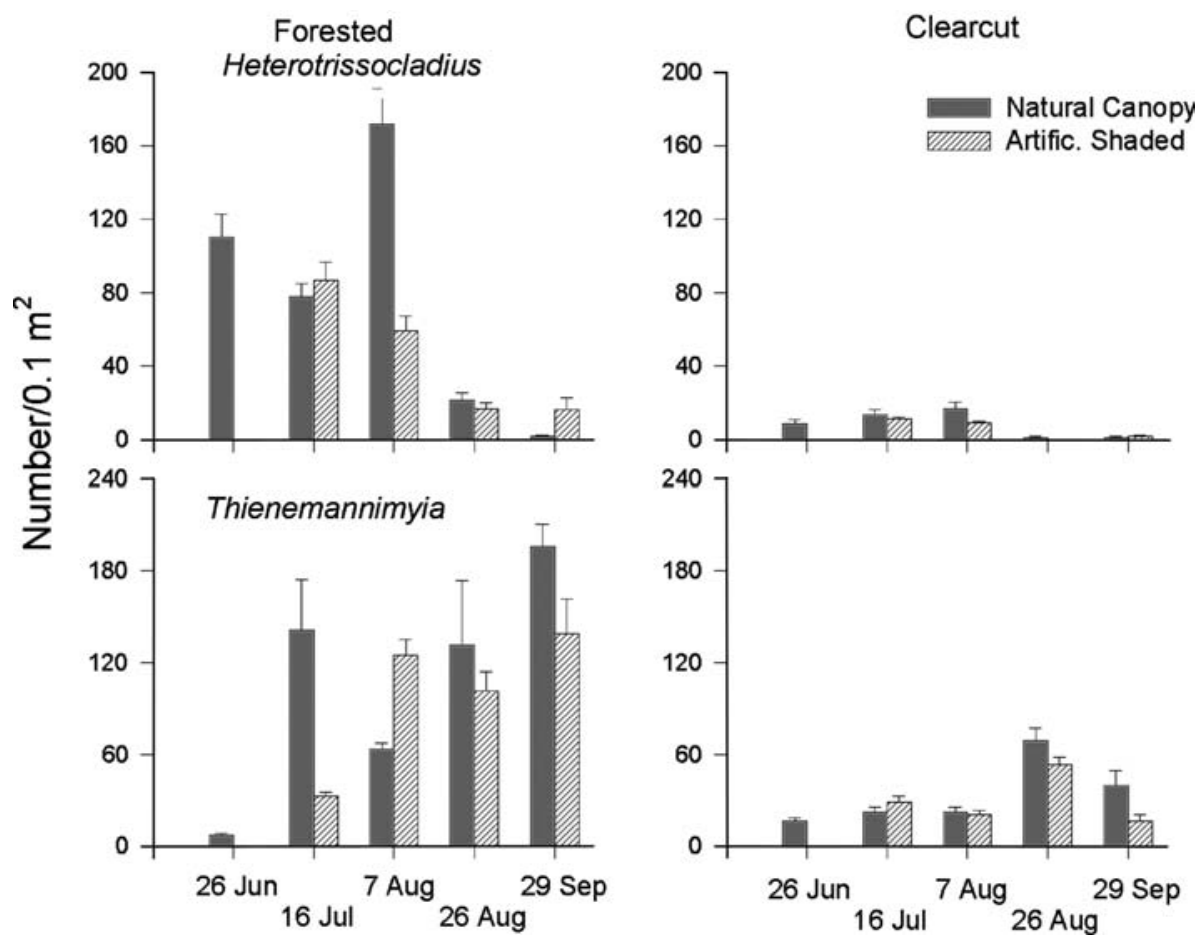

Figure 2. Mean $(+1 \mathrm{SE}, n=6)$ densities of Heterotrissocladius hirtapex and Thienemannimyia sp. (both Chironomidae) in two streams at HBEF during summer 1989.

(Fig. 4), but was significantly lower in shaded channels $(p<0.05)$ on all subsequent sample dates than in the other two treatments (which were similar) (Fig. 4).

Macroinvertebrate responses to these manipulations differed according to taxon. Ephemerella subvaria density was similar among treatments initially but was significantly higher $(p<0.01)$ in the open channels than in the shaded and shaded + sucrose channels on 18 November (Fig. 5). Density of Chironomidae did not differ significantly $(p>0.30)$ between the open and shaded channels on any sample date (Fig. 5) but tended to be higher $(p<0.10)$ in the shaded + sucrose channels when bacterial density was high (from 3 October onwards); it was significantly higher $(p<0.01)$ in the shaded + sucrose channels only on 18 November (Fig. 5). Heptageniid density was similar $(p>0.40)$ among treatments on the first two sample dates; on the last two sample dates, however, it was significantly lower $(p<0.01)$ in the shaded + sucrose channels than either the open or shaded channels, the latter 2 being similar $(p>0.50)$ (Fig. 5).
Macroinvertebrates that were abundant but showed no response to our manipulations included: Isonychia (Ephemeroptera); various Plecoptera (such as Acroneuria, Paragnetina, Taeniopteryx, and early instar Capniidae); filterfeeding trichopterans in the genera Chimarra, Cheumatopsyche, and Hydropsyche; and Annelida. Other macroinvertebrates appeared sporadically (Coleoptera such as Psephenidae and Elmidae) and were not abundant enough to analyze statistically.

\section{Discussion}

The importance of allochthonous inputs to streams was demonstrated by higher macroinvertebrate density in the forested (HBEF) stream despite both forested and clear-cut streams having similar macroinvertebrate composition and relative abundance. Higher CPOM in the forested stream probably resulted in higher shredder (especially Leuctra tenella) density. FPOM produced by shredder activity (Wallace \& Webster, 

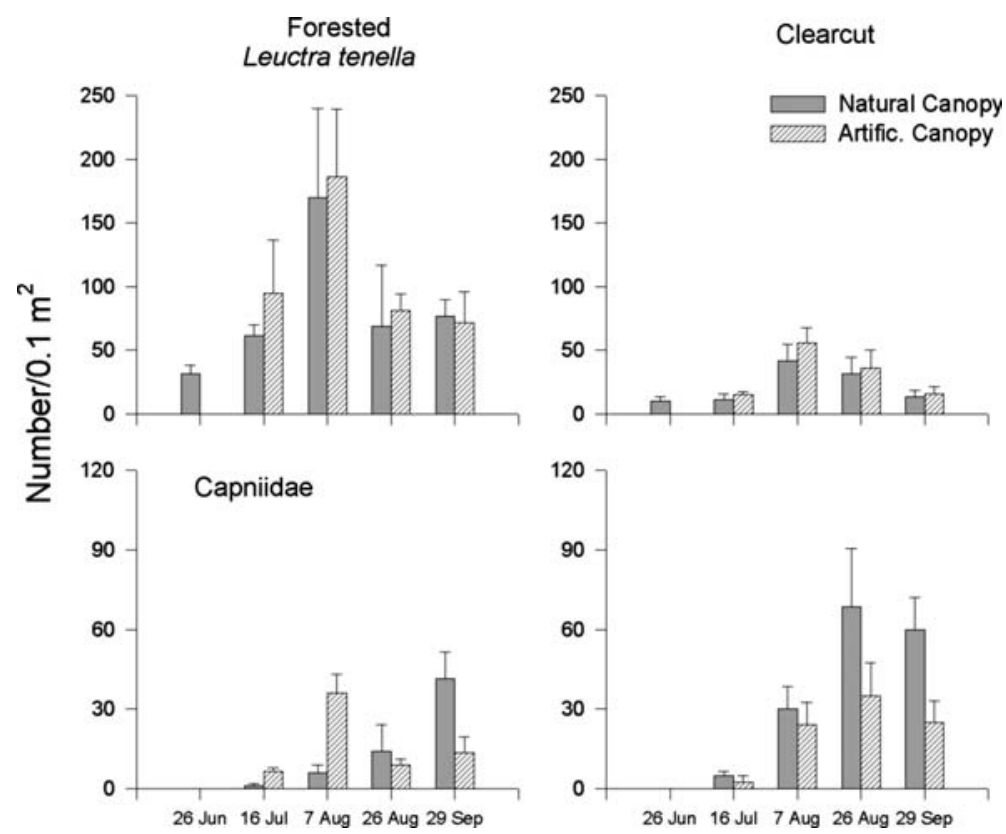

Figure 3. Mean $(+1 \mathrm{SE}, n=6)$ density of Leuctra tennela and Capniidae (both Plecoptera) in two streams at HBEF during summer 1989.

1996) may explain the higher density of the chironomid Heterotrissocladius, a gatherer, in the forested stream. The chironomid predator, Theinemannimyia, also was more abundant in the forested stream, probably because of more abundant prey. While other macroinvertebrates were present in these streams, scrapers/grazers were rare and those present in the clear-cut stream were also present in the forested stream. Our results suggest that the two streams had detritus-based food chains despite the more open canopy of the clearcut stream. Hall et al. (2001) came to similar conclusions studying Bear Brook (second orderstream downstream from our study) and Hubbard Brook (fifth order, open-canopy stream) although the Bear Brook macroinvertebrate community was slightly more reliant on allochthonous carbon sources than Hubbard Brook.

Streams with open canopies generally have higher algal abundance and more scrapers/grazers than closed-canopy, forested streams (Vannote et al., 1980; Behmer \& Hawkins, 1986; Fuller et al., 1986; Wallace \& Gurtz, 1986; Feminella et al., 1989; Wallace \& Webster, 1996); also, total macroinvertebrate abundance usually is higher in open- than in closed-canopy streams (reviewed by Feminella \& Hawkins, 1995; Wallace \& Webster,
1996). However, in the open-canopy, clear-cut stream, the low abundance of algae and benthic CPOM resulted in a macroinvertebrate community with few scrapers/grazers and shredders and a lower total macroinvertebrate density than in the forested stream. In 1983 (immediately post clearcut), the clear-cut stream had high nutrient concentrations and grazers were abundant (Ulrich et al., 1993). Our experiments began 6 years after the clear-cut and benthic CPOM was still less abundant than the forested stream (i.e., lower accumulation of CPOM in cages from clear-cut stream) despite re-growth of terrestrial vegetation. Studies in clear-cut catchments have shown decreased CPOM inputs to streams initially, but allochthonous inputs return to near-reference levels in about 5-10 years (Webster et al., 1992). Reduced nutrient inputs to streams in logged catchments have been observed during the re-vegetation phase (5-15 years) and sometimes were lower than pre-disturbance levels at mid-successional stages (Likens et al., 1970; Brown et al., 1973; Vitousek, 1977; Webster et al., 1992). Our low macroinvertebrate density in the clear-cut stream probably reflected low autochthonous sources of carbon resulting from nutrient limitation and either low allochthonous inputs or poor retention of allo- 

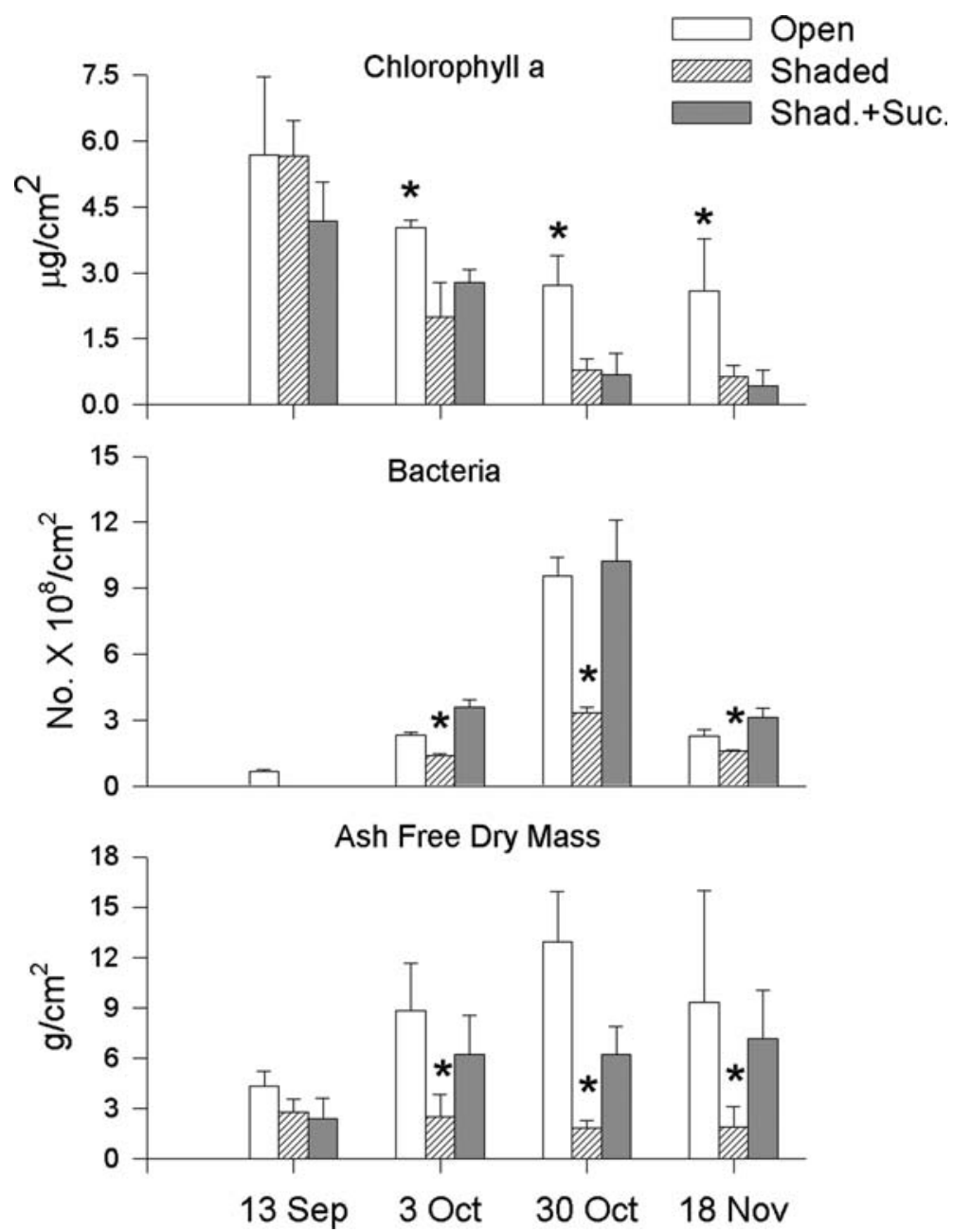

Figure 4. Mean ( $+1 \mathrm{SE}, n=6)$ chlorophyll $a$ concentration, bacteria density and ash free dry mass of periphyton in open, shaded and shaded + sucrose channels in Augusta Creek, Kellogg Biological Station, September-November 1990. (*above the bars indicate significant differences among treatments at $p<0.05$ ).

chthonous inputs. Therefore, bottom-up controls appear to be influencing macroinvertebrate populations in the clear-cut stream.

\section{Augusta Creek - shading and sucrose amendment study}

Algal abundance was higher in Augusta Creek (chlorophyll $a$ concentrations of 3-7 $\mu \mathrm{g} / \mathrm{cm}^{2}$ ) than in the Hubbard Brook tributaries $\left(<0.2 \mu \mathrm{g} / \mathrm{cm}^{2}\right)$, and we observed higher scraper/grazer densities. In the Augusta Creek experiment, only Ephemerella subvaria had a higher density in the open channels; but these high densities did not occur until November when E. subvaria nymphs were larger.
In laboratory feeding studies, late instars of $E$. subvaria showed greater growth when fed a mixed assemblage of diatoms (Fuller \& Desmond, 1997), whereas early instars grew well on either diatom or detrital diets. Therefore, the gradual shift we observed from equal densities of E. subvaria among treatments in early October to highest densities in open channels by mid-November may have been due to a shift toward herbivory as nymphs grew.

Chironomidae density was highest in channels with low algal and high bacterial abundance (shaded + sucrose channels). Warren et al. (1964) observed a similar response by Chironomidae when they added sucrose to an entire stream. Also, Hall (1995) has shown chironomids rely more 

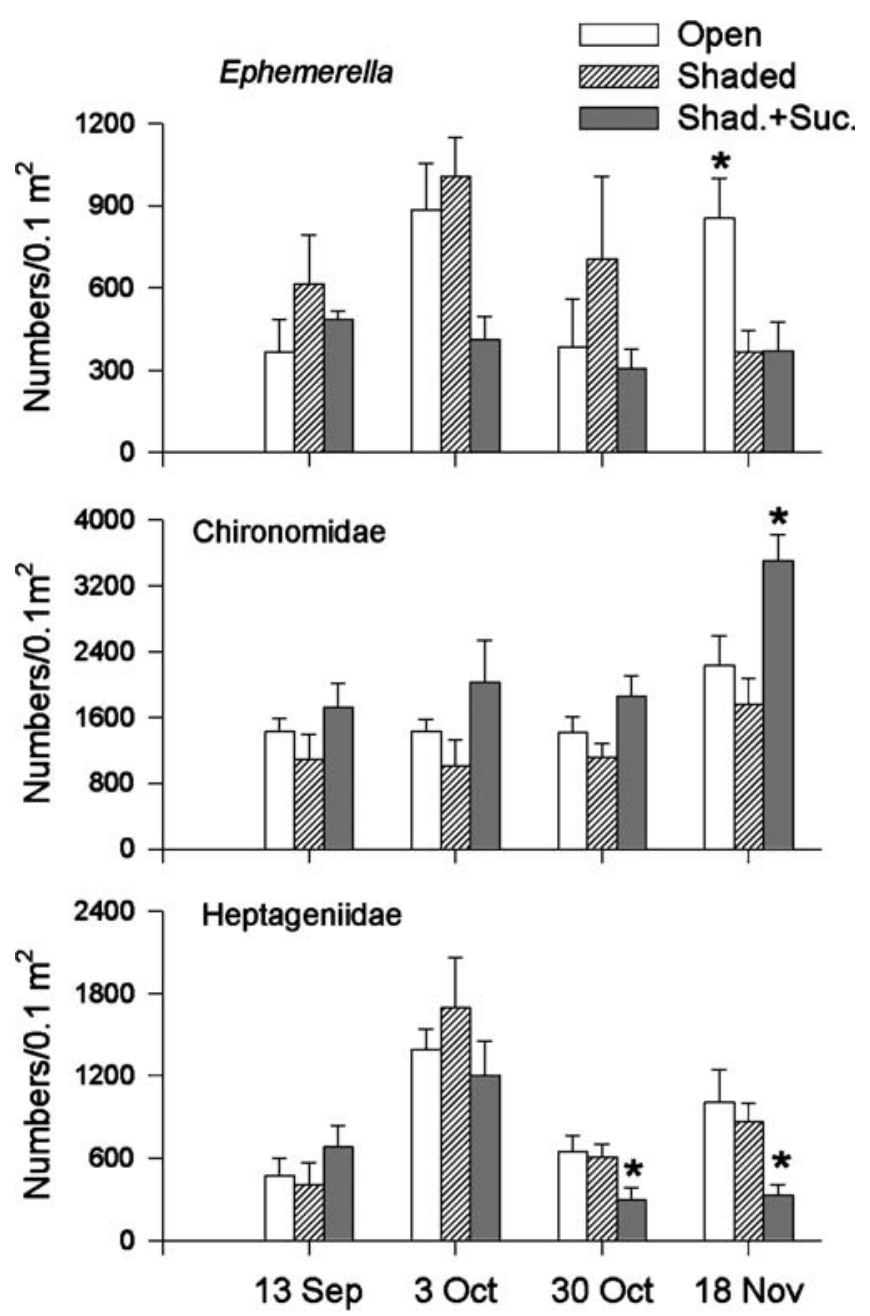

Figure 5. Mean $(+1$ SE, $n=6)$ density of Ephemerella subvaria, Chironomidae and Heptageniidae in open, shaded, and shaded + sucrose channels in Augusta Creek, Kellogg Biological Station, September-November 1990 (*above the bars indicate significant differences among treatments at $p<0.05$ ).

heavily than most other taxa on bacterial carbon in headwater streams. All of these observations suggest a positive relationship between microbial abundance and chironomid abundance. Hall (1995) and Hall \& Meyer (1998) suggested that chironomids rely on carbon in exopolymers, and Couch \& Meyer (1992) have shown carbon in bacterial exopolymers to be nine times greater than carbon in bacterial cell biomass. Others also have shown that carbon in bacterial extracellular polymers was more abundant than carbon in bacterial cell biomass (Jahn \& Nielsen, 1998). Bacteria produce greater amounts of exopolymers when carbon is in excess supply (reviewed by Decho, 1990). Therefore, if the sucrose amendment elevated bacterial production, there may have been greater exopolymer biomass in the shaded + sucrose channels than the open channels despite similar bacterial density. While speculative, a potentially higher exopolymer biomass in the shaded + sucrose channels may explain the higher chironomid density in these channels.

The only macroinvertebrates showing a negative response to increased bacterial abundance were heptageniid mayflies (Stenacron interpunctatum, Stenonema spp., and Leucrocuta sp.). We suspect that this decrease in abundance had little to do with food resource use because their numbers did not decrease in the shade only treatment, but instead they may have been related to fouling 
of gill surfaces. Many mayflies and stoneflies from the shaded + sucrose channels had thick bacterial films on their dorsal surfaces which may have hindered respiration for the heptageniids, at least.

Bacteria have long been recognized as mineralizers in streams; however, only recently has the significance of the heterotrophic microbial community as a main food source for macroinvertebrates been demonstrated. Studies of filter-feeding black flies both in the field and laboratory have suggested that bacteria (or bacterially derived carbon) may be the main food of these insects (Edwards \& Meyer, 1987; Hauer \& Benke, 1987; Fuller et al., 1988; Fuller \& Fry, 1991; Hall, 1995; Couch et al., 1996; Hershey et al., 1996; Hall \& Meyer, 1998). Similarly, the mayflies Stenonema and Paraleptophlebia have been shown to use bacteria as an energy source (Edwards \& Meyer, 1990; Hall, 1995; Fuller \& Desmond, 1997; Hall \& Meyer, 1998). Thus, several recent studies have shown that bacteria or bacterially derived carbon can be a main energy source for some macroinvertebrates.

Macroinvertebrates that use bacteria as a main source of energy have relatively short gut residence times, for example, 30-60 min. in black flies and chironomids (Mulla \& Lacey, 1976; Wotton, 1978; Welton et al., 1991). Additionally, Mattingly (1987) showed that species of the mayfly Paraleptophlebia (a collector-gatherer) had gut passage times of $<2.0 \mathrm{~h}$. Therefore, some stream macroinvertebrates may move large quantities of material through their guts, stripping the easily digested bacteria and their exopolymers. This feeding strategy is common among marine polychaetes and terrestrial annelids and may be more common among stream invertebrates than current information suggests. In comparison, other stream macroinvertebrates may need longer gut residence times to allow for digestion of larger 'packets of energy' (e.g., algae or CPOM in the case of Tipula; Vannote \& Sweeney, 1985).

Minshall (1978) re-emphasized the importance of autotrophy in streams at a time when much of the literature was dominated by papers on detritus processing and the importance of detritus to stream macroinvertebrates. More recently attention has focused on the importance of algae as a source of energy for stream macroinvertebrates. Thus, the current notion suggests that energy flows from algae directly to herbivorous macroinverte- brates in open-canopy streams. However, studies have also shown a positive correlation between algal and bacterial abundance in streams (Geesey et al., 1978; Hepinstall \& Fuller, 1994; but see Findlay et al., 1993), and others have shown the importance of algal DOC to bacteria (Kaplan \& Bott, 1982, 1989). The macroinvertebrate use of bacteria (supported by algal DOC) may involve an additional 'step' in the food chain: algal DOC $\rightarrow$ bacteria and their exopolymers $\rightarrow$ macroinvertebrates; this additional step with associated inefficiencies in energy transfer, reduces the amount of algal energy available to macroinvertebrate detritivores. With recent data accumulating on the use of bacterial exopolymers by stream macroinvertebrates (Hall, 1995; Couch et al., 1996; Wotton, 1996; Hall \& Meyer, 1998), we believe the pathway from algal DOC to bacteria to macroinvertebrates should receive more attention in future studies of energy flow in streams.

Stable isotope studies have shown how terrestrial carbon sources move through stream food webs (Hamilton \& Lewis, 1992; Rosenfeld \& Roff, 1992; Junger \& Planas, 1994; Huryn et al., 2001), and Hall and Meyer (1998) have shown the importance of a bacterial link between allochthonous carbon and higher trophic levels. Studies on open-canopy streams have also shown the relative importance of autochthonous carbon sources to stream food webs (Rosenfeld \& Roff, 1992; Zah et al., 2001), although some studies of open-canopy systems have encountered problems because $\delta C$ values changed with season, sources of DIC and sometimes with water velocity (McLeod \& Barton, 1998; Finlay et al., 1999). No studies that we know of have labeled bacterial carbon in opencanopy streams [similar to what Hall and Meyer (1998) did in forested streams] and so we do not know the exact path of autochthonous carbon from algae to higher trophic levels. However, given our results and the high production values for Chironomidae in some streams (Benke 1998), the algal-microbe-insect pathway may be more important than previously thought.

Macroinvertebrate density was very low in Hubbard Brook tributaries where chlorophyll $a$ concentrations, bacterial densities and periphyton AFDM were also low. In contrast, macroinvertebrate densities in Augusta Creek were an order of 
magnitude higher and chlorophyll $a$ concentration, bacterial density and AFDM were also very high relative to Hubbard Brook values. These data suggest that macroinvertebrate density was at least in part determined by food resource availability (i.e., bottom-up controls). This is further supported by the lower macroinvertebrate abundance in the clear-cut stream versus the forested stream where the former had lower benthic CPOM. However, our manipulations in Hubbard Brook tributaries occurred during the summer and early fall when allochthonous inputs were low and macroinvertebrate shredders were not abundant. Leaf shredders have life cycles cued to autumnal inputs of leaf material to streams (Wallace \& Webster, 1996) and the shredders were noticeably absent from our samples (Capniidae appearing late in our samples). We suggest future studies should consider examining the predictive power of these measures for estimating macroinvertebrate density or production. Bourassa \& Cattaneo (1998) showed that phosphate concentration was a better predictor of macroinvertebrate biomass than light or chlorophyll $a$ concentrations because the latter was sensitive to over-grazing by stream insects or fish. Therefore, we recommend including measures of nutrient concentrations in future studies, and we suggest that care be taken to consider life cycles of the species present and the importance of temporal variability in macroinvertebrate density/production.

In summary, our manipulations of algae and bacteria suggest that specific macroinvertebrate taxa respond differently to changes in these food resources. Stream grazers are known to track algal abundance (Feminella \& Hawkins, 1995), but only recently, through the use of stable isotopes, have chironomids been shown to rely heavily on bacterial carbon (Hall, 1995; Hall \& Meyer, 1998). In complement to these carbon tracer experiments, which describe where individuals acquire their energy, our experiment examined the scale of an entire community and quantified the population level responses to manipulations at the base of an aquatic food web. Our results suggest that the heterotrophic microbial community may be an important food resource for some stream macroinvertebrates and the microbe-to-macroinvertebrate link in the food chain should be more closely examined.

\section{Acknowledgements}

We thank Dr S. Findlay of the Institute of Ecosystem Studies for his data on AFDM, algal, bacterial and water chemistry in the study at HBEF. We express our appreciation to Drs D. Lawson and M. Klug for their advice and assistance while we conducted the study in Augusta Creek at Kellogg Biological Station. C.R. Fuller kindly lent a hand in the construction of the 24 channels. This research was funded by Research Opportunity Awards to RLF from the National Science Foundation (HBEF through the Ecosystems Program; Augusta Creek through the Ecology Program). Also, we are grateful to Dr Robert Bode for identifying the chironomid, Heterotrissocladius hirtapex Saether. Dr R. Arnold's assistance with the data analysis was greatly appreciated. Finally, we wish to thank Dr R. Mackay for her helpful comments and suggestions on earlier versions of the manuscript. Colgate University Research Council provided funds for publication costs.

\section{References}

Behmer, D. J. \& C. P. Hawkins, 1986. Effects of overhead canopy on macroinvertebrate production in a Utah (USA) stream. Freshwater Biology 16: 287-300.

Benke, A. C., 1998. Production dynamics of riverine chironomids: extremely high biomass turnover rates of primary consumers. Ecology 79: 899-910.

Benke, A. C. \& D. I. Jacobi, 1994. Production dynamics and resource utilization of snag-dwelling mayflies in a blackwater river. Ecology 75: 1219-1232.

Benke, A. C. \& J. B. Wallace, 1980. Trophic basis of production among net-spinning caddisflies: implications for food web analysis. Ecology 61: 108-118.

Benke, A. C. \& J. B. Wallace, 1997. Trophic basis of production among riverine caddisflies: implications for food web analysis. Ecology 78: 1132-1145.

Bormann, F. H. \& G. E. Likens (eds), 1979. Pattern and Process in a Forested Ecosystem. Springer-Verlag, New York.

Bourassa, N. \& A. Cattaneo, 1998. Control of periphyton biomass in Laurentian streams (Quebec). Journal of the North American Benthological Society 17: 420-429.

Brown, G. W., A. R. Gahler \& R. B. Marston, 1973. Nutrient losses after clear-cut logging and slash burning in the Oregon Coast Range. Water Resources Research 7: 11891199.

Couch, C. A. \& J. L. Meyer, 1992. Development and composition of the epixylic biofilm in a blackwater river. Freshwater Biology 27: 43-51. 
Couch, C. A., J. L. Meyer \& R. O. Hall Jr, 1996. Incorporation of bacterial extracellular polysaccharide by black fly larvae (Simuliidae). Journal of the North American Benthological Society 15: 289-299.

Decho, A. W., 1990. Microbial exopolymer secretions in ocean environments: their role(s) in food webs and marine processes. Oceanography \& Marine Biology 28: 73-153.

Edwards, R. T. \& J. L. Meyer, 1987. Bacteria as a food source for black fly larvae in a blackwater river. Journal of the North American Benthological Society 6: 241-250.

Edwards, R. T. \& J. L. Meyer, 1990. Bacterivory by depositfeeding mayfly larvae (Stenonema spp.). Freshwater Biology 24: $453-462$.

Feminella, J. W. \& C. P. Hawkins, 1995. Interactions between stream herbivores and periphyton: a quantitative analysis of past experiments. Journal of the North American Benthological Society 14: 465-509.

Feminella, J. W., M. E. Power \& V. H. Resh, 1989. Periphyton responses to invertebrate grazing and riparian canopy in 3 northern California coastal streams. Freshwater Biology 22: 445-457.

Findlay, S., K. Howe \& D. Fontvieille, 1993. Bacterial-algal relationships in streams of the Hubbard Brook Experimental Forest. Ecology 74: 2326-2336.

Finlay, J. C., M. E. Power \& C. Cabana, 1999. Effects of water velocity on algal carbon isotope ratios: implications for river food web studies. Limnology \& Oceanography 44: 11981203.

Fuller, R. L. \& C. Desmond, 1997. Influence of food quality on the growth of early and late instars of three mayfly (Ephemeroptera) species. Archiv für Hydrobiologie 131: 161-173.

Fuller, R. L. \& T. J. Fry, 1991. The influence of temperature and food quality on the growth of Hydropsyche betteni (Trichoptera) and Simulium vittatum (Diptera). Journal of Freshwater Ecology 6: 75-86.

Fuller, R. L. \& R. J. Mackay, 1981. Effects of food quality on the growth of three Hydropsyche species (Trichoptera: Hydropsychidae). Canadian Journal of Zoology 59: 1133-1140.

Fuller, R. L., J. A. Roelofs \& T. J. Fry, 1986. The importance of algae to stream insects. Journal of the North American Benthological Society 5: 290-296.

Fuller, R. L., T. J. Fry \& J. A. Roelofs, 1988. Influence of different food types on the growth of Simulium vittatum (Diptera) and Hydropsyche betteni (Trichoptera). Journal of the North American Benthological Society 7: 197-204.

Geesey, R. M., J. W. Costerton \& R. B. Green, 1978. Sessile bacteria: an important component of the microbial population in small mountain streams. Limnology \& Oceanography 23: $1214-1223$.

Hall, R. O., 1995. The use of a stable carbon isotope addition to trace bacterial carbon through a stream. Journal of the North American Benthological Society 14: 269-277.

Hall, R. O. \& J. L. Meyer, 1998. The trophic significance of bacteria in a detritus-based stream food web. Ecology 79: 1995-2012.

Hall, R. O., J. B. Wallace \& S. L. Eggert, 2000. Organic matter flow in stream food webs with reduced detrital resource base. Ecology 81: 3445-3463.
Hall, R. O., G. E. Likens \& H. M. Malcolm, 2001. Trophic basis of invertebrate production in 2 streams at the Hubbard Brook Experimental Forest. Journal of the North American Benthological Society 20: 432-447.

Hamilton, S. K. \& W. M. Lewis Jr, 1992. Stable carbon and nitrogen isotopes in algae and detritus from the Orinoco River floodplain, Venezuela. Geochimica et Cosmochimica Acta 56: 4237-4246.

Hauer, F. R. \& A. C. Benke, 1987. Influence of temperature and river hydrograph on black fly growth rates in a subtropical, blackwater river. Journal of the North American Benthological Society 6: 251-261.

Hepinstall, J. A. \& R. L. Fuller, 1994. Periphyton reactions to different light and nutrient levels and the response of bacteria to thee manipulations. Archiv für Hydrobiologie 131: 161-173.

Hershey, A. E., R. W. Merritt, M. C. Miller \& J. S. McCrea, 1996. Organic matter processing by larval blackflies in a temperate woodland stream. Oikos 75: 524-532.

Hobbie, J. E., R. J. Daley \& S. Jasper, 1977. Use of nucleopore filters for counting bacteria by fluorescence microscopy. Applied Environmental Microbiology 33: 1225-1228.

Huryn, A. R., R. H. Riley, R. G. Young, C. J. Arbuckle, K. Peacock \& G. Lyons. 2001. Temporal shift in contribution of terrestrial organic matter to consumer production in a grassland river. Freshwater Biology 46: 213-226.

Jahn, A. \& P. H. Nielsen, 1998. Cell biomass and exopolymer composition in sewer biofilms. Water, Science \& Technology 37: 17-24.

Junger, M. \& D. Planas. 1994. Quantitative use of stable carbon isotope analysis to determine the trophic base of invertebrate communities in a boreal forest lotic system. Canadian Journal of Fisheries \& Aquatic Sciences 51: 52-61.

Kaplan, L. A. \& T. L. Bott, 1982. Diel fluctuations of DOC generated by algae in a Piedmont stream. Limnology \& Oceanography 27: 1091-1100.

Kaplan, L. A. \& T. L. Bott, 1989. Diel fluctuations in bacterial activity on streambed substrata during vernal algal blooms: effects of temperature, water chemistry and habitat. Limnology \& Oceanography 34: 718-733.

Likens, G. E., F. H. Bormann, N. M. Johnson, D. W. Fisher \& R. S. Pierce, 1970. The effects of forest cutting and herbicide treatment on nutrient budgets in the Hubbard Brook watershed-ecosystem. Ecological Monographs 40: 23-47.

MacLeod, N. A. \& D. R. Barton, 1998. Effects of light intensity, water velocity, and species composition on carbon and nitrogen stable isotope ratios in periphyton. Canadian Journal of Fisheries \& Aquatic Sciences 55: 1919-1925.

Mattingly, R. L., 1987. Handling of coarse and fine particulate organic matter by the aquatic insects Paraleptophlebia gregalis and Paraleptophlebia temporalis (Ephemeroptera: Leptophlebiidae). Freshwater Biology 18: 255-266.

McCutchan, J. H. \& W. M. Lewis. 2002. Relative importance of carbon sources for macroinvertebrates in a Rocky Mountain stream. Limnology \& Oceanography 47: 742-752.

Minshall, G. W., 1978. Autotrophy in streams. BioScience 28: 767-771.

Mulla, M. S. \& L. A. Lacey, 1976. Feeding rates of Simulium larvae on particulates in natural streams (Diptera: Simuliidae). Environmental Entomology 5: 283-287. 
Rosenfeld, J. S. \& J. C. Roff, 1992. Examination of the carbon base in southern Ontario streams using stable isotopes. Journal of the North American Benthological Society 11: 110.

Ulrich, K. E., T. M. Burton \& M. P. Oemke, 1993. Effects of whole tree harvest on epilithic algal communities in headwater streams. Journal of Freshwater Ecology 8: 8392.

Vannote, R. L. \& B. W. Sweeney, 1985. Larval feeding and growth rates of the stream cranefly Tipula abdominalis in gradients of temperature and nutrition. Proceedings of the National Academy of Sciences 137: 119-128.

Vannote, R. L., G. W. Minshall, K. W. Cummins, J. R. Sedell \& C. E. Cushing, 1980. The river continuum concept. Canadian Journal of Fisheries \& Aquatic Sciences 37: 130137.

Vitousek, P. M., 1977. The regulation of element concentrations in mountain streams in the northeastern United States. Ecological Monographs. 47: 65-87.

Wallace, J. B. \& M. E. Gurtz, 1986. Response of baetid mayflies (Ephemeroptera) to catchment logging. American Midland Naturalist 115: 25-41.

Wallace, J. B. \& J. R. Webster, 1996. The role of macroinvertebrates in stream ecosystem function. Annual Review of Entomology 41: 115-1139.

Wallace, J. B., M. R. Whiles, S. Eggert, T. F. Cuffney, G. J. Jugthart \& K. Chung, 1995. Long-term dynamics of coarse particulate organic matter in three Appalachian Mountain streams. Journal of the North American Benthological Society 14: 217-232.

Wallace, J. B., S. L. Eggert, J. L. Meyer \& J. R. Webster, 1999. Effects of resource limitation on a detrital-based ecosystem. Ecological Monographs 69: 409-442.

Warren, C. E., J. H. Wales, G. E. Davis \& P. Duodoroff, 1964. Trout production in an experimental stream enriched with sucrose. Journal of Wildlife Management 28: 617-660.

Webster, J. R., S. W. Golladay, E. F. Benfield, J. L. Meyer, W. T. Swank \& J. B. Wallace, 1992. Catchment disturbance and stream response: an overview of stream research at Coweeta Hydrologic Laboratory. In Boon, P. J. \& G. E. Petts (eds), River Conservation and Management. John Wiley \& Sons, Ltd., New York: 231-253.

Welton, J. S., M. Ladle, J. A. B. Bass \& R. T. Clarke, 1991. Grazing of epilithic chironomid larvae at two different water velocities in recirculating streams. Archiv für Hydrobiologie 121: 405-418.

Wotton, R. S., 1978. The feeding rate of Metacnephia tredeaimatum larvae (Diptera: Simulium) in a Swedish lake outlet. Oikos 30: 121-125.

Wotton, R. S., 1996. Colloids, bubbles, and aggregates - a perspective on their role in suspension feeding. Journal of the North American Benthological Society 15: 127-135.

Zah, R., P. Burgherr, S. M. Bernasconi \& U. Uehlinger, 2001. Stable isotope analysis of macroinvertebrates and their food sources in a glacier stream. Freshwater Biology 46: $871-882$ 